Silva, L., Dissanayake, P., Kumarasiri, B. and Soorige, D., 2021. Customer loyalty towards sustainable hotels: Case studies in Sri Lanka. In: Sandanayake, Y.G., Gunatilake, S. and Waidyasekara, K.G.A.S. (eds). Proceedings of the $9^{\text {th }}$ World Construction Symposium, 9-10 July 2021, Sri Lanka. [Online]. pp. 231-243. DOI: https://doi.org/10.31705/WCS.2021.20. Available from: https://ciobwcs.com/papers/

\title{
CUSTOMER LOYALTY TOWARDS SUSTAINABLE HOTELS: CASE STUDIES IN SRI LANKA
}

\author{
Lakeesha Silva $^{1}$, Piumi Dissanayake ${ }^{2}$, Binashi Kumarasiri ${ }^{3}$ and Dumindu Soorige ${ }^{4}$
}

\begin{abstract}
The hotel sector is directly combined with customer loyalty as it has become increasingly obvious by incorporating its' antecedents with customer satisfaction and trust. Customer loyalty is influenced by customer satisfaction of hospitality service when it is significantly related to service quality. Sustainability is an important concept that can adapt to achieving customer loyalty in the Sri Lankan hotel sector. Indeed, most conventional hoteliers in Sri Lanka do not have the idea of success in achieving customer loyalty through the sustainability concept. Also, despite the abundance of research on the concept of sustainability, a gap in literature could be identified, when it comes to analysing the customer loyalty aspects toward sustainable hotels in Sri Lanka. This study is therefore aimed to bridge the gap that exists in the literature to prove the success of adopting the concept of sustainability in achieving customer loyalty. A qualitative research approach with two case studies was used to achieve the aim of the study. The selected cases include two green-certified five-star hotels which are under the topmost sustainable hotels in Sri Lanka according to Sri Lanka Tourism Development Authority. A total of 10 interviews were conducted from both cases. The collected data were analysed using content analysis. The customer loyalty aspects were identified on the deriving basis of self-influence factors of customers and their consideration of benefits in sustainable hotels. The study unveils an analysis of the interconnection between sustainable hotels and customer loyalty. The findings provide the path to conventional hotels to identify the success of implementing sustainability concept in achieving customer loyalty.
\end{abstract}

Keywords: Considerations of benefits, Customer loyalty; Self-influence factors; Sustainability.

\section{INTRODUCTION}

Sustainability is a concept that can be defined through interconnected domains namely, environment, economy, and society (Baumgartner and Ebner, 2010). Sustainability has become a major area among different kind of buildings such as commercial buildings, industrial buildings, hotels, and hospitals (Abdellatif and Al-Shamma'a, 2014). The hotel industry has been identified by many researchers as the most capable sector in applying sustainability concept compared to other sectors while hotels tend to integrate with its world widely (Zhang et al., 2010). A sustainable hotel can be identified as an entity with a structure that has made important environmental improvements for minimising its

\footnotetext{
${ }^{1}$ Department of Building Economics, University of Moratuwa, Sri Lanka, silvalakeesha@gmail.com

${ }^{2}$ Department of Building Economics, University of Moratuwa, Sri Lanka, piumid@uom.lk

${ }^{3}$ Department of Building Economics, University of Moratuwa, Sri Lanka, binashik@uom.lk

${ }^{4}$ Department of Building Economics, University of Moratuwa, Sri Lanka, sooriged@uom.lk
} 
impact on the natural environment (Jones et al., 2014). Sustainable hotels have an important role in reducing the negative impact on the environment since hotels consume energy, water, waste, materials, and land much more efficiently than buildings simply built to code (Chen, 2015). In today's world, hotels have developed platforms to address sustainability concept in response to requests from guests, investors, and stakeholders as they tend to consider the financial and non-financial benefits of it (Assante et al., 2012). Among those stakeholders, customers play a major role in gaining service from sustainable hotels as sustainability performance influence their decisions of preventing environmental impacts (Robinot and Giannelloni, 2015).

Customer loyalty has been identified as a key factor in the Sri Lankan hotel sector as it is the most important strategic mechanism of best practices among hotels (Miththapala et al., 2013). The customer loyalty of the hotel sector is created through customer satisfaction of hospitality service when it is significantly related to sustainability which is a part of service quality (Cheng and Rashid, 2013). Many hotels' customers tend to value hotels that adopt eco-friendly practices and demonstrate sustainability (Liat et al., 2014). Customer loyalty with hotels' sustainability performance is seen as essential for their success and the hotel industry's existence depends on the effective way to alert customers to their sustainable operations (Smith et al., 2015).

Numerous studies have been conducted by researchers of developed countries by exploring ways of achieving customer loyalty in the hotel sector through sustainability but, in Sri Lanka, this is yet to be studied. Contexts of developed and developing countries are different from each other. Thus, the studies conducted in hotel sector of developed countries cannot be directly generalised with the context of developing countries (Sambhanthan and Good, 2012). This proves that there is a necessity in investigating the way of achieving customer loyalty of the Sri Lankan hotel sector through the sustainability concept, which so far has not been addressed yet in the research. Therefore, this paper aimed at bridging this knowledge gap that exists in the literature to prove the success of adopting sustainability in achieving customer loyalty.

\section{LITERATURE REVIEW}

\subsection{CUSTOMER LOYALTY IN HOTEL SECTOR}

Anuwichanont et al. (2011) explained customers are more influenced by the existence of the hotel sector among stakeholders as their decisions of gaining service from hotels is more important. Moreover, customers are influenced by sustainable activities in different ways as, circumstances of sustainability impact customers' decisions (Anuwichanont et al., 2011). Therefore, customers are willing to be loyal to the sustainable practices of hotels directly and influenced by circumstances of sustainability (Chen, 2015). The customer loyalty of the hotel sector will be created through customer satisfaction of hospitality service which is significantly related to the service quality (Cheng and Rashid, 2013). Hotels consume a vast amount of energy, water, and discharge a huge amount of waste so that, the negative impact on the environment should be highly concerned (Kasimu et al., 2012). A greater hotels' participation towards sustainability by committing to those identified impacts, the customer loyalty is influenced in numerous ways (Han et al., 2009). 


\subsection{CuStomer Loyalty in SuStainable Hotel Sector}

Keeping a long-term guest loyalty is undoubtedly essential for hotels' long-term success as well as having customer loyalty in environmental practices is undeniably fundamental for the success of sustainable hotel management (Han et al., 2009). In recent years, hoteliers are active in establishing an enduring relationship with conscious customer loyalty regarding sustainability by making various entities (Jiang and Kim, 2015). Nowadays, hoteliers want to improve competitiveness through promoting a sustainable hospitality service by implementing eco-friendly attitudinal profiles of customers and influencing ecological buying behaviours (Jiang and Kim, 2015). The sustainability of hotels influences customer loyalty based upon two main aspects, namely, self-influence factors of customers (refer Section 2.2.1) (Chen, 2015), and consideration of benefits that occurred through sustainable hotels (refer Section 2.2.2) (Blackman and Rivera, 2010).

\subsubsection{Self-influence Factors of Customers}

There are customers of the hotel sector that, motivates by their own will due to the sustainability performance through their preference and willingness of being loyal to sustainability practices (Chen, 2015). As further explained by Chen (2015), it positively impacts customer loyalty through their individual decisions of consuming sustainable hotels. There are three main self-influence factors, namely 'Behavioural intention of customers', 'Environmental concern of customers' and 'customer attitudes of preferring natural resources. These factors are described in the below subsections respectively.

\section{- Behavioural Intention of Customers}

Behavioural intention is the customers' willingness to pay certain ranges of prices for products or services by leaving positive remarks about the product or service (Han et al., 2009). Guests in hotels as the primary stakeholders tend to prefer to deal with hotel services that are less harmful to the natural environment (Lita et al., 2014). The customers who are likely to pay for a sustainable hotel, are typically more sophisticated and to varying degree of concern about environmental issues (Lita et al., 2014). People who are more familiar with the hospitality of hotels are more conscious about sustainability and the hotel industry currently faces increasing demands to achieve environmental responsiveness (Anuwichanont et al., 2011). These customers believe in the value provided by sustainable hotels which can be identified as, environmentally friendly properties whose managers are eager to institute programs that save water, energy, and reduce solid waste and money (Lita et al., 2014).

\section{- Environmental Concern of Customers}

Anuwichanont et al. (2011) identified customers' environmental concern as an individual orientation of each hotel guest towards the environmental impacts. Nowadays many individuals and communities have paid attention to the importance of engaging in ecofriendly sustainable behaviours which proves the customer attitudes toward environmentally, economically and socially sustainable behaviours (Chen, 2011). When hotel guests are conscious of the importance of environmental issues, it increases the level of responsibility of consuming an environmentally, economically, and socially sustainable hotel service (Chen, 2015). A Research by Pathak (2015) has proved that about $80 \%$ of guests consider themselves as environmentally conscious customers and $62 \%$ of guests tend to concern about environmental issues when selecting a hotel. 


\section{- Customer Attitudes of Preferring Natural Resources}

Nowadays, customers tend to prefer natural environmental factors rather than gaining comfort through artificial energy consumption factors in their leisure in hotels (Yusof and Jamaludin, 2014). There is a positive impact on sustainability and a reason for many environmental, economic and social benefits (Yusof and Jamaludin, 2014). When it comes to, architectural design of the hotel local materials like clay tiles, bamboo and local timber dominate the design approach of hotels and provide an aesthetic appearance that guests prefer to feel (Jauhari, 2014). On the other hand, using daylights instead of using artificial lighting fixtures, through building orientation and glass walls, is a trending demand among hotel guests with attitudes of preferring natural resources (Wang, 2012). This factor is established as "use only natural lighting during daytime hours" in the framework of adopting green practices among hoteliers (Mousavi et al., 2017).

\subsubsection{Consideration of Benefits in Sustainable Hotels}

There are hotel customers who do or do not have any personal willingness to consume sustainable hotels but, they would choose sustainable hotels considering benefits such as low operational cost, increasing overall image, and market differentiation, believing in the influence of those benefits towards their customer loyalty (Blackman and Rivera, 2010). Three main factors come under the category of consideration of benefits in sustainable hotels, namely, 'Low operational cost of sustainable hotels', 'overall image of sustainable hotels' and 'Market differentiation of sustainable hotels'. These three (03) factors are described in the below subsections respectively.

\section{- Low Operational Cost of Sustainable Hotels}

Adopting sustainability practices for a hotel helps to reduce operational cost while improving the performance of the hotel activities (Kularatne et al., 2019). Moreover, the operational cost of a hotel can be more effective when it tends to adopt sustainability practices such as using energy-efficient lighting, using natural ventilation and daylighting. Hotels can be identified as a facility which consumes huge amounts of energy, non-recyclable good, and natural resources while contributing greatly to environmental degradation, therefore, sustainability is a solution not only reduces environmental harm but also cut back operational cost (Jiang and Kim, 2015). Reduction of operational cost is directly connected with the price that customer should pay to gain the service from the hotel. If the hotel guest perceives the fairness of price of hospitality service it helps to grow step by step optimistic emotion towards the hotel by keeping a better customer loyalty (Fernando, 2019).

\section{- Overall Image of Sustainable Hotels}

The overall image of a hotel can be identified as a combination of impressions, beliefs and thoughts which collect consumer perceptions towards attributes of a hotel (Chen, 2015). A sustainable hotel image is a positively effective factor towards consumers' perceptions and increases their revisit intention for a future stay (Kularatne et al., 2019). A better sustainable application covering the triple bottom line including environment, economy and society helps to establish a brand image so that customers tend to consume hotel service with a considerable demand (Dissanayake et al., 2016). Furthermore, studies conducted by the IHEI (2020), reveal that $90 \%$ of hotel guests prefer to stay in a hotel that reduces environmental impact and adopt sustainable practices as it improves the hotels' overall image. The overall image created by the sustainability of a 
hotel is very important to influence the degree of customer loyalty (Cheng and Rashid, 2013).

\section{- Market Differentiation of Sustainable Hotels}

Currently, both the Sri Lankan government and hoteliers have led an attempt to develop programs to promote environmental sustainability among hotels (Fernando, 2019). IFC has stated that the "Greening Sri Lankan hotels" program conducted by the Sri Lankan government, play an important role in developing knowledge about energy efficiency and better water utilisation to make hotels keep in market differentiation. If a hotel tends to adopt the most possible sustainable applications, it helps to create a unique hospitality service and offer a unique experience for guests (Marques et al., 2016). The same authors stated that an effective market differentiation of a hotel through a sustainable policy improves customer loyalty as it impacts customer satisfaction. A sustainable hotel can create a great marketing strategy that helps to be differentiated and providing customers with what they need (Jauhari, 2014).

However, when it comes to the Sri Lankan context, despite the abundance of research on the concept of sustainability, a gap in literature could be identified when it comes to analysing the customer loyalty aspects, i.e., self-influence factors of customers (refer Section 2.2.1) and consideration of benefits that occurred through sustainable hotels (refer Section 2.2.2) toward sustainable hotels in Sri Lanka. Thus, in bridging this knowledge gap, this study intended to investigate the adaptability of sustainability in achieving customer loyalty. The subsequent section discusses the methodology adopted in bridging the knowledge gap.

\section{RESEARCH METHODOLOGY}

This study aims to investigate the ways of achieving customer loyalty of the hotel sector through the sustainability concept, which so far has not been addressed as a research in Sri Lanka. Thus, the research question of the study was developed as follows:

$R Q$ : "How sustainability could affect customer loyalty in the Sri Lankan hotel sector?"

A qualitative research approach was followed since it is considered to be the most suitable approach in achieving the aim of the study based on the research question (Yin, 2014). The study followed an in-depth exploration of the contemporary phenomenon, i.e., investigate the ways of achieving customer loyalty of hotel sector through sustainability concept within its real-world context, with a 'how' type of research question. Thus, adopting the case study research strategy can be justified. A holistic multiple case design (Yin, 2014) was selected with "customer loyalty" as the unit of analysis while sustainable hotels being the case boundary. Yin (2014) recommended that the number of cases should be decided based on literal replications or theoretical replications expected through the study. Therefore, this study was limited to two (02) expecting literal replications. Further, the high data saturation experienced during data analysis justified the adequacy of the number of cases selected. The selected two (02) cases were the representation of topmost sustainable hotels among the few sustainable hotels in Sri Lanka. Both hotels are constructed and currently operates by following 'sustainability' as the main theme. Moreover, interviewees were selected based on the purposive sampling which falls under the non-probability sampling where the researcher has used expertise to select a sample that is most useful to attain the purpose of the research, which is to investigate how the 
sustainable practices would affects the customer loyalty. Thus, a total of ten (10) interviews were conducted from both cases. Table 1 provides a profile of selected cases and interviewees.

Table 2: Profile of case studies and interviewees

\begin{tabular}{|c|c|c|c|c|}
\hline Case & Respondent & $\begin{array}{l}\text { Management/ } \\
\text { Customer }\end{array}$ & $\begin{array}{l}\text { Designation of } \\
\text { managerial level } \\
\text { respondents }\end{array}$ & $\begin{array}{c}\text { Work } \\
\text { experience of } \\
\text { managerial } \\
\text { respondents }\end{array}$ \\
\hline Case A & AM1 & Management & Chief Engineer & 15 \\
\hline \multirow{4}{*}{$\begin{array}{l}\text { A green certified five- } \\
\text { star hotel } \\
\text { Located at Uva Province } \\
\text { A building complex } \\
\text { spread across } 38 \text { acres of } \\
\text { land }\end{array}$} & AM2 & Management & Environmentalist & 15 \\
\hline & $\mathrm{AC} 1$ & Customer & - & - \\
\hline & $\mathrm{AC} 2$ & Customer & - & - \\
\hline & $\mathrm{AC} 3$ & Customer & - & - \\
\hline $\begin{array}{l}\text { Case B } \\
\text { A green certified five- } \\
\text { star hotel }\end{array}$ & BM1 & Management & $\begin{array}{l}\text { Learning and } \\
\text { Development } \\
\text { Manager }\end{array}$ & 25 \\
\hline $\begin{array}{l}\text { Located at North- } \\
\text { Western Province }\end{array}$ & BM2 & Management & $\begin{array}{l}\text { Sustainability in } \\
\text { charge }\end{array}$ & 15 \\
\hline \multirow{3}{*}{$\begin{array}{l}\text { A building complex } \\
\text { spread across } 208 \text { acres } \\
\text { of land, which the hotel } \\
\text { area is around } 8 \text { acres }\end{array}$} & $\mathrm{BC} 1$ & Customer & - & - \\
\hline & $\mathrm{BC} 2$ & Customer & - & - \\
\hline & $\mathrm{BC} 3$ & Customer & - & - \\
\hline
\end{tabular}

The interview guideline focused on customer loyalty aspects identified through the literature review. Interviewees were requested to elaborate their answers as per the current exposure to the customer loyalty aspects. The collected data was analysed using content analysis. The findings were extracted through analysis of case findings using an abductive analysis.

\section{RESEARCH FINDINGS AND ANALYSIS}

A detailed description of the cross-case analysis of Case A and B are presented in two subsections: one describes the "Self-influence factors of customers (Section 4.1)" and one describes "Consideration of Benefits in Sustainable Hotels (Section 4.2)".

\subsection{SELF-INFLUENCE FACTORS OF CUSTOMERS}

According to the literature findings, three main self-influence factors make customers loyal to sustainable hotels (refer Section 2.2.1). The perceptions of both managerial level and customer level respondents towards these three factors are analysed in Sections 4.1.1 to 4.1.3 while Section 4.1.4 discusses a unique self-influence factor, which was derived through analysis of research findings specific to the Sri Lankan context.

\subsubsection{Behavioural Intention of Customers}

The willingness comes from customers' behaviour in being sophisticated while getting satisfied about sustainability related services are the behavioural intentions of customers. They are loyal to sustainable hotels with the intention to pay money in a certain range 
while leaving a positive remark. Managerial level respondents of both cases agreed that there are customers who tend to visit both hotels considering their behavioural intentions. Respondent AM1 justified this fact by stating "it is very rare to find customers who visit our hotel just to spend a leisure time because our hotel is based upon the green concept and customers who appreciate it". When it comes to customers' perspective, AC1, AC3, $\mathrm{BC} 1$, and $\mathrm{BC} 2$ clearly mentioned that their knowledge and awareness on sustainability is the cause of being loyal with these hotels through behavioural intention. On the other hand, respondent, $\mathrm{BC} 3$ also mentioned that his behavioural intention influences him to prefer sustainable hotels where he stated, "I think my behavioural intention is created through present social media evolution. Nowadays, people tend to promote about sustainability and publish impacts of environmental pollution along with evident real incidents. So that, it influences me to appreciate sustainability even in a hotel stay". It seems customers tend to choose sustainable hotels as their behaviour influences from awareness on sustainability.

\subsubsection{Environmental Concern of Customers}

The consciousness about environmental pollution among customers influences them to deal with sustainable hotels to integrate with sustainability initiatives. It contributes to the hotel industry for attracting customers with environmental concern. Management of both cases reviewed that, there are customers who tend to be loyal to these hotels due to their concern for the environment. Managerial level respondent AM2 stated, "there are customers who do not aware of the sustainability practical scenarios but, very fond of the environment". Respondent BM1 explained that "our hotel is in the high priority level in Sri Lanka for customers who care about the environment. So, majority of the customers come to this hotel, are with high environmental concern. For them, each sustainability practice is important". However, feedbacks from managerial level respondents proved that awareness or knowledge on sustainability does not impact on environmental concern and respondent $\mathrm{BC} 3$ who introduced himself as a customer who do not have much knowledge on sustainability stated "considering the current incidents on environmental pollution in Sri Lanka, my concern towards the environment is influenced so I appreciate this sustainable hotel and its practices". Respondent AC2 stated "I am not aware of a lot of sustainability practices, but I know it is environmentally friendly so that, there is a minimum impact on nature" and he further mentioned his environmental concern is highly influenced to prefer this hotel and to be loyal with it.

\subsubsection{Customer Attitudes of Preferring Natural Resources}

Some customers are looking forward to experiencing the spectacularism of natural resources through their visit to sustainable hotels. The main concern of these customers is to avoid technological and typical applications of conventional hotels. Thus, the customers with attitudes of preferring natural resources tend to choose the service from sustainable hotels. Both the management respondents from both cases mentioned that preferring natural resources is one of the basic and initial intentions of customers who visit these sustainable hotels. On the other hand, managerial level respondent BM1 stated, "the majority of the customers who visit this hotel tend to prefer, natural rock pool, outdoor dining, cave dining, and walking around forest rather than staying inside an airconditioned room as their attitudes directly interrelated with sustainability practices and to experience them". Further, all the managerial level respondents explained that, if customers require a more technologically advanced hospitality service, which includes, 
full air conditioned, and high energy consumed, closed environment in a crowded city area, they will not be loyal to these sustainable hotels. This fact was further justified by customer level respondents from both cases and especially AC1 stated "my attitudes are integrated with natural resources in the hotel sector, so that, when choosing a hotel, I concern about the availability of natural resources such as natural ventilation and day lighting which reaches my attitudes and intentions".

\subsubsection{Educational Purposes of Customers}

The educational purposes of customers are a novel self-influence factor that has been investigated through the analysis of empirical research findings. Managerial level respondents from both cases suggested that other than customers' behavioural intention, environmental concern, and attitudes of preferring natural resources, customers tend to visit these sustainable hotels for their educational purposes. Mainly, managerial level respondents from Case A stated "nowadays, people tend to get to know about sustainability. So that, researchers, and environmentalists choose to have a valuable stay in green-certified hotels to observe the sustainable practices". It was further apparent through findings that customers such as researchers, university students, environmentalists tend to visit Case B for their educational purposes as this hotel is considered as the best sustainable model in the Sri Lankan hotel sector. Additionally, respondent BM1 stated "most of them tend to publish their findings and communicate with others about the hotel which continuously leads to increase our customer base and their loyalty". Each year, there is a certain customer base that arrives at these hotels due to their educational purposes and it makes them loyal toward hotels. All the managerial level respondents presented the reason for this self-influence factor mentioning that, the unavailability of many sustainable hotels in Sri Lanka. Hence, the customers with educational purposes tend to visit and achieve their purposes which will influence them to be loyal.

Table 2 provides the identified self-influence factors that affect customer loyalty towards sustainable hotels in Sri Lankan context.

Table 2: Customer loyalty aspects of Sri Lankan sustainable hotels-self-influence factors

\begin{tabular}{|c|c|c|c|}
\hline $\begin{array}{l}\text { Self-influence } \\
\text { factors of } \\
\text { customers } \\
\end{array}$ & $\begin{array}{l}\text { Customers } \\
\text { who take into } \\
\text { consideration }\end{array}$ & Feedback by management & Remarks \\
\hline $\begin{array}{l}\text { Behavioural } \\
\text { intention }\end{array}$ & $\begin{array}{l}\mathrm{AC} 1, \mathrm{BC} 1, \\
\mathrm{BC} 3\end{array}$ & $\begin{array}{l}\text { These customers are } \\
\text { intelligent customers who } \\
\text { appreciate sustainability. }\end{array}$ & $\begin{array}{l}\text { Customers with sustainability } \\
\text { awareness/ knowledge influence } \\
\text { from this factor. }\end{array}$ \\
\hline $\begin{array}{l}\text { Environmental } \\
\text { concern }\end{array}$ & $\begin{array}{l}\mathrm{AC} 1, \mathrm{AC} 2 \\
\mathrm{AC} 3, \mathrm{BC} 1 \\
\mathrm{BC} 2, \mathrm{BC} 3\end{array}$ & $\begin{array}{l}\text { The major influenced factor } \\
\text { among sustainability. }\end{array}$ & $\begin{array}{l}\text { Sustainability knowledge does } \\
\text { not matter as customers who care } \\
\text { about environment influence } \\
\text { from this factor. }\end{array}$ \\
\hline $\begin{array}{l}\text { Customer } \\
\text { attitudes of } \\
\text { preferring } \\
\text { natural } \\
\text { resources }\end{array}$ & $\begin{array}{l}\mathrm{AC} 1, \mathrm{AC} 3 \\
\mathrm{BC} 2, \mathrm{BC} 3\end{array}$ & $\begin{array}{l}\text { This is the competitive factor } \\
\text { to win customers over } \\
\text { conventional hotels as more } \\
\text { conventional hotels are } \\
\text { located in urban areas. }\end{array}$ & $\begin{array}{l}\text { The location of hotels is the } \\
\text { major influence on this factor } \\
\text { because a location which expose } \\
\text { to more natural resources attract } \\
\text { customers. (E.g.: hotels near to } \\
\text { forest, sea) }\end{array}$ \\
\hline
\end{tabular}




\begin{tabular}{llll}
\hline $\begin{array}{c}\text { Self-influence } \\
\text { factors of } \\
\text { customers }\end{array}$ & $\begin{array}{c}\text { Customers } \\
\text { who take into } \\
\text { consideration }\end{array}$ & Feedback by management & \multicolumn{1}{c}{ Remarks } \\
\hline $\begin{array}{l}\text { Educational } \\
\text { purposes* }\end{array}$ & AC1, BC1 & $\begin{array}{l}\text { A special opportunity among } \\
\text { sustainable hotels to reach } \\
\text { the educational sector. }\end{array}$ & $\begin{array}{l}\text { The published articles and books } \\
\text { generate customer loyalty } \\
\text { without any cost as it influences } \\
\text { customers. }\end{array}$ \\
\hline
\end{tabular}

*Represents the new self-influence factor that has been identified through data collection.

\subsection{CONSIDERATION OF BENEFITS IN SUSTAINABLE HOTELS}

Other than self-influence factors, customers consider the benefits of sustainable hotels as a factor, to be loyal to sustainable hotels. Those benefits facilitate enhancing the customer loyalty of sustainable hotels while influencing them to visit continuously. According to the literature review findings, there are three (03) benefits that customer takes into consideration in being loyal with sustainable hotels (refer Section 2.2.3). The perceptions of both managerial level and customer level respondents towards these three benefits are analysed in Sections 4.2.1 to 4.2.3. However, it is revealed that low operational cost is not relatable with hotel customers in Sri Lanka (refer Section 4.2.1).

\subsubsection{Low Operational Cost of Sustainable Hotels}

The operational cost of sustainable hotels is comparatively less due to sustainable practices although it incurred high cost at the implementation stage. Especially, managerial level respondents of case B mentioned that there are a lot of sustainability practices such as, use of solar power plants for electricity generation, application of natural ventilation and use of daylighting, and use of LED lights, which directly supports to reduce operational cost. Apart from the above sustainable practices, case A use in-site Reverse Osmosis (RO) plant, in-site Effluent Treatment Plant (ETP) and STP (Sewage Treatment Plant). These practices have facilitated Case A to reduce the water consumption of the hotel. This is because, the whole water consumption is managed using treated seawater which directly reduces operational cost. On the other hand, when considering the impact of low operational cost on customer loyalty, there should be a price reduction, which customer must pay for the hospitality service they receive. In this context, managerial level respondents of Case A stated "customers will not get the real benefit of sustainability through the prices, as hoteliers like us tend to value the speciality of the sustainability concept. There are only a few hotels which are based upon the sustainability whereas, our management tends to value it by increased prices compared to other luxury hotels in Sri Lanka". In this context, it became evident that customers do not receive the benefit of low operational cost arisen due to sustainability, as both cases do not reduce the price of hospitality service.

\subsubsection{Overall Image of Sustainable Hotels}

A hotel creates its overall image through sustainability, and it helps to have a competitive advantage among other hotels as well. Simply, the value that has created from the overall image of hotels facilitates to attract more customers as loyal customers. It is because, there is a certain range of customers who consider the overall image of a hotel when deciding their loyalty. Managerial level respondents of both cases described that overall image is the factor which influences the first impression of a hotel for the new customers who visit these hotels for the first time. Managerial level respondent BM1 further stated "some customers do not see the sustainability practices inside the hotel until they visit 
this hotel. Until that, the main reason for choosing this hotel for their stay is the overall image which portrays the sustainability". Thereby, it is evident that the overall image of the hotel is mostly benefited for newly attended customers. It is not only the new customers but also it supports to increase the continuous visitation of customers who continuously visit sustainable hotels being loyal due to overall image. These customers will serve as advocates to the hotel by giving free publicity among the society in addition to the other media such as newspapers, well-established websites for customer reviews, social media and the hotel's official website.

\subsubsection{Market Differentiation of Sustainable Hotels}

As the Sri Lankan hotel sector consists of a comparative number of conventional hotels than sustainable hotels, a hotel that follows sustainability can differentiate in the whole hotel market which in another way, attract customers. The sustainability practices followed by the hotel make it a differentiated entity that reaches customers who consider market differentiation. Market differentiation of both cases have been defined by managerial level respondents in a very positive manner as they believe customers have been achieved through market differentiation they have created. Hotel management of both cases believes adaptation of sustainability practices as a marketing tool. This is because, sustainability is the main pillar that acts in being differentiating in the market. Further, respondent AM2 stated "one of our main activities is to provide a unique experience for customers in a beautiful living setup through a luxury amidst nature and wildlife so that, our hotel is differentiated in the market through this sustainability marketing tool". On the other hand, respondent BM1 stated "this hotel has already established its name in the market due to the created market differentiation of sustainability". In this context, it is evident that market differentiation of Case A and B is a factor which exists in hotel market for achieving customer loyalty as sustainable hotels. When it comes to customer level respondents, respondent AC2 stated "it positively impacts customers like me to choose sustainable hotels as there is a certain group of customers who visit hotels considering its' market differentiation". Table 3 depicts the consideration of benefits in which would affects the customer loyalty towards sustainable hotels in Sri Lankan context

Table 3: Customer loyalty aspects of Sri Lankan sustainable hotels - consideration of benefits

\begin{tabular}{|c|c|c|c|}
\hline $\begin{array}{l}\text { Consideration of } \\
\text { benefits in hotels }\end{array}$ & $\begin{array}{l}\text { Customers who } \\
\text { take into } \\
\text { consideration }\end{array}$ & Feedback by management & Remarks \\
\hline $\begin{array}{l}\text { Low operational } \\
\text { cost }^{* *}\end{array}$ & - & $\begin{array}{l}\text { The price that customer must } \\
\text { pay is not reduced as } \\
\text { sustainable hotels value their } \\
\text { uniqueness }\end{array}$ & $\begin{array}{l}\text { Price is high compared } \\
\text { to other conventional } \\
\text { luxury hotels. }\end{array}$ \\
\hline Overall image & $\begin{array}{l}\mathrm{AC} 2, \mathrm{AC} 3, \mathrm{BC} 2, \\
\mathrm{BC} 3\end{array}$ & $\begin{array}{l}\text { It reaches a new customer } \\
\text { base who did not know about } \\
\text { these hotels }\end{array}$ & $\begin{array}{l}\text { Depend on the progress } \\
\text { of sustainability as the } \\
\text { main pillar is } \\
\text { sustainability. }\end{array}$ \\
\hline $\begin{array}{l}\text { Market } \\
\text { differentiation }\end{array}$ & $\begin{array}{l}\mathrm{AC} 2, \mathrm{AC} 3, \mathrm{BC} 2, \\
\mathrm{BC} 3\end{array}$ & $\begin{array}{l}\text { These hotels differentiate from } \\
\text { other hotels through } \\
\text { sustainability }\end{array}$ & $\begin{array}{l}\text { Selected hotels are the } \\
\text { two topmost } \\
\text { sustainable 5-star } \\
\text { hotels in Sri Lanka. }\end{array}$ \\
\hline
\end{tabular}

** Represents the inapplicable benefit in Sri Lankan sustainable hotels which was identified through data collection. 


\section{DISCUSSION}

By reviewing the literature, two aspects were revealed which describes how the sustainable practices of hotels would affect the customer loyalty: namely; self-influence factors of customers (refer Section 2.2.1), whereas the customers of the hotel sector that motivates by their own will due to the sustainability performance through their preference and willingness of being loyal to sustainability practices (Chen, 2015) and the consideration of benefits that could gain via the sustainable hotels (Blackman and Rivera, 2010) (refer Section 2.2.2). The literature findings were identified in general and were not specific to Sri Lankan hotel industry. However, these findings were almost similar to the Sri Lankan context conferring to the case study findings. For instance, In the aspect of self-influence factors, three factors were revealed by the literature, namely; behavioural intention of customer, environmental concern of customers and customer attitudes of preferring natural resources which were also confirmed through the case study refer (Sections 2.2.1 and 4.1], except the factor "educational purposes" which was solely identified to the Sri Lankan context revealing that there is a separate customer base who are visiting these hotels in order to achieve objectives of research, books, documentary programs and other educational activities and become loyal with these hotels (refer Section 4.1.3). In addition to the self-influence factors, the other aspect identified was the consideration of benefits that could gain through sustainable hotels. Most of these benefits identified through the literature were also analogous to the Sri Lankan context, such as overall image and market differentiation (refer Sections 4.2.1 and 4.2.2). However, even though, Kularatne et al. (2019) and Jiang and Kim (2015) have identified "low operational cost of sustainable hotels" also as a benefit, case study findings revealed that low operational cost holds a different perspective in Sri Lankan hotels towards the fact of granting service to customers for low prices (refer Section 4.2.1) portraying that it is not applicable to the Sri Lankan context.

\section{CONCLUSIONS}

Sustainability is a concept which has the capability of enduring and maintaining itself while making biological systems to remain healthy, diverse, and productive over time. When considering the sustainability of hotel sector, it creates environmental improvements to the structure for the purpose of minimising its' impact on environment. Sustainable hotels have a vast potential on achieving customer loyalty through a better sustainability performance. Thus, this paper was aimed at analysing the aspects where the sustainability could the affects the customer loyalty in Sri Lankan hotel industry. Two aspects were identified through the literature review such as self-influence factors of customers and the consideration of benefits that could gain via the sustainable hotels (refer Sections 2.2.1 and 2.2.2), which could achieve customer loyalty through sustainability practices. Behavioural intention, environmental concern, customer attitudes of preferring natural resources and educational purposes were the four (04) factors identified respective to the aspect of self-influence factors in the Sri Lankan context (refer Section 4.1). Moreover, two (02) facts were revealed following the aspect of consideration of benefits in sustainable hotels which are pertinent to the sustainable hotels in Sri Lanka; namely, overall image (refer Section 4.2.2) and market differentiation refer Section 4.2.3) which were slightly differed from the literature findings. The verdicts of this paper claims on the importance of sustainability in attaining the customer loyalty in the hostels in Sri Lanka by identifying several aspects. Thus, the knowledge engendered 
through this research study would enable the hoteliers including researchers to be aware of the importance in adapting sustainability which will correspondingly leads to conquer customer loyalty that is still unaware amid the most of conventional hotels in Sri Lanka.

\section{REFERENCES}

Abdellatif, M. and Al-Shamma'a, A., 2014. Review of sustainability in buildings. Sustainable Cities and Societies, 14, p. 172.

Mousavi A., S., Hoşkara, E. and Woosnam, K.M., 2017. Developing a model for sustainable hotels in Northern Cyprus. Sustainability, 9(11), p. 2101.

Anuwichanont, J., Mechinda, P., Serirat, S., Lertwannawit, A. and Popaijit, N., 2011. Environmental sustainability in the Thai hotel industry. International Business \& Economics Research Journal (IBER), 10(11), pp. 91-100.

Assante, L.M., Wen, H.I., Lottig, K. and Hotels, S., 2012. An empirical assessment of residents' attitudes for sustainable tourism development: A case study of O 'ahu, Hawaii. Journal of Sustainability and Green Business, 1(1), pp. 1-27.

Baumgartner, R.J. and Ebner, D., 2010. Corporate sustainability strategies: Sustainability profiles and maturity levels. Sustainable Development, 18(2), pp. 76-89.

Blackman, A. and Rivera, J., 2011. Producer-level benefits of sustainability certification. Conservation Biology, 25(6), pp. 1176-1185.

Cheng, B.L. and Rashid, M.Z.A., 2013. Service quality and the mediating effect of corporate image on the relationship between customer satisfaction and customer loyalty in the Malaysian hotel industry. Gadjah Mada International Journal of Business, 15(2), pp. 99- 112.

Chen, R.J., 2011. The facts of the weather extreme events in the United States: Is there a trend? Tennessee Research and Creative Exchange, 4(4), pp. 14- 21.

Chen, R.J., 2015. From sustainability to customer loyalty: A case of full-service hotels' guests. Journal of Retailing and Consumer Services, 22, pp. 261-265.

Dissanayake, D., Tilt, C. and Xydias-Lobo, M., 2016. Sustainability reporting by publicly listed companies in Sri Lanka. Journal of Cleaner Production, 129, pp. 169-182.

Fernando, W.B.J.A.J., 2019. Factors associated with customer satisfaction towards customer loyalty among star grade hotels. Journal of Asian Business Strategy, 9(2), p. 193.

Han, H., Hsu, L.T.J. and Lee, J.S., 2009. Empirical investigation of the roles of attitudes toward green behaviors, overall image, gender, and age in hotel customers' eco-friendly decision-making process. International Journal of Hospitality Management, 28(4), pp.519-528.

IHEI, 2020. The Resource for the hotel industry [Online]. Pierrefonds QC, Hotel Resource. Available from: https://www.hotelresource.com/HR-more-id-967227490.html [Accessed 30 April 2021].

Jauhari, V. ed., 2014. Managing sustainability in the Hospitality and Tourism Industry: Paradigms and Directions for the Future. CRC Press.

Jiang, Y. and Kim, Y., 2015. Developing multi-dimensional green value. International Journal of Contemporary Hospitality Management, 27(2), pp. 1- 20.

Jones, P., Hillier, D. and Comfort, D., 2014. Sustainability in the global hotel industry. International Journal of Contemporary Hospitality Management. p. 6.

Kasimu, A.B., Zaiton, S. and Hassan, H., 2012. Hotels' involvement in sustainable tourism practices in Klang Valley, Malaysia. International Journal of Economics and Management, 6(1), pp. 21-34.

Kularatne, T., Wilson, C., Månsson, J., Hoang, V. and Lee, B., 2019. Do environmentally sustainable practices make hotels more efficient? A study of major hotels in Sri Lanka. Tourism Management, 71, pp. 213-225.

Lita, R.P., Surya, S., Ma'Ruf, M. and Syahrul, L., 2014. Green attitude and behaviour of local tourists towards hotels and restaurants in West Sumatra, Indonesia. Procedia Environmental Sciences, 20, pp. 261-270.

Marques, P.D., Guijarro, M. and Carrilero, A., 2016. The use of customer-centric philosophy in hotels to improve customer loyalty. Journal of Business \& Industrial Marketing, pp. 339- 348. 
Miththapala, S., Jayawardena, C.C. and Mudadeniya, D., 2013. Responding to trends: Environmentally friendly sustainable operations (ESO) of Sri Lankan hotels. Worldwide Hospitality and Tourism Themes, 5(5), pp. 442-455

Pathak, M., 2015. Do travelers prefer eco-friendly hotels? [Online]. Uttar Pradesh, Hotelogix. Available from: https://www.hotelogix.com/blog/2015/05/25/do-travelers-prefer-eco-friendly-hotels [Accessed 25 April 2021].

Robinot, E. and Giannelloni, J.L., 2010. Do hotels "“green" attributes contribute to customer satisfaction? Journal of Services Marketing, pp. 157- 169.

Sambhanthan, A. and Good, A., 2012. Implications for improving accessibility to e-commerce websites in developing countries: a study of hotel websites. International Journal of Knowledge-Based Organizations (IJKBO), 2(2), pp. 1-20.

Sewwandi, A.M.L., 2017. Impact of sustainable practices on customer satisfaction in hotel industry (Evidence from boutique hotels in Southern province, Sri Lanka) (Doctoral dissertation, Uva Wellassa University of Sri Lanka).

Wang, R., 2012. The investigation of green best practices for hotels in Taiwan. Procedia-Social and Behavioral Sciences, 57, pp. 140-145.

Yin, R., 2014. Case Study Research: Design and Methods, $5^{\text {th }}$ ed. Thousand Oaks, CA: SAGE

Yusof, Z.B. and Jamaludin, M., 2014. Barriers of Malaysian green hotels and resorts. Procedia-Social and Behavioral Sciences, 153, pp. 501-509.

Zhang, J.J., Joglekar, N. and Verma, R., 2010. Developing measures for environmental sustainability in hotels: An exploratory study. The scholarly commons, p. 5. 